Scientific Journal of Informatics

Vol. 7, No. 1, May 2020

p-ISSN 2407-7658

http://journal.unnes.ac.id/nju/index.php/sji

e-ISSN 2460-0040

\title{
RETRACTED: Boyer-Moore String Matching Algorithm and SHA512 Implementation for JPEG/Exif File Fingerprint Compilation in DSA
}

\author{
Rachmad Fitriyanto ${ }^{1}$, Anton Yudhana ${ }^{2}$, Sunardi $^{3}$ \\ ${ }^{1}$ Information System Departmen, STMIK PPKIA Tarakanita Rahmawati Tarakan, Indonesia \\ ${ }^{2,3}$ Electrical Engineering Department, Universitas Ahmad Dahlan, Indonesia \\ Email: 1rachmad7477@ gmail.com, ${ }^{2}$ yudhana@ee.uad.ac.id, ${ }^{3}$ sunardi@mti.uad.ac.id
}

\section{Retracted}

This paper is retracted by editor due to publication ethics missconducted by author (simultaneously publication in other journal).

Similar article has appeared in

http://jurnalnasional.ump.ac.id/index.php/JUITA/article/view/4413

The document and its content has been removed from Scientific Journal of Informatics Vol. 7, No. 1, May 2020, and reasonable effort should be made to remove all references to this article. 